\title{
Analisis Margin Pemasaran Kue Telur Gabus pada KWT Melati di Desa Bungin Jaya Kecamatan Semendawai Timur Kabupaten OKU Timur
}

\author{
Dwi Mutiara \\ Sekolah Tinggi Ilmu Eonomi Syari'ah Al - Mujaddid \\ Jln. Panglima Sudirman No.1 Lintas Sabak Jambi. Kabupaten Tanjung Jabung Timur. Provinsi Jambi. 36563. \\ e-mail: tiara.umy@gmail.com
}

\begin{abstract}
ABSTAK
Tujuan dari penelitian ini adalah untuk: 1) mengetahui besar pendapatan usaha pengolahan kue telur gabus oleh KWT Melati di Desa Bungin Jaya Kecamatan Semendawai Timur Kabupaten OKU Timur, 2) mengetahui pola rantai pemasaran kue telur gabus oleh KWT Melati di Desa Bungin Jaya Kecamatan Semendawai Timur Kabupaten OKU Timur, 3) mengetahui keuntungan dan margin pemasaran kue telur gabus pada setiap saluran pemasaran oleh KWT Melati di Desa Bungin Jaya Kecamatan Semendawai Timur Kabupaten OKU Timur, 4) mengetahui perbedaan nilai bagian yang diterima (farmer's share) KWT Melati karena perbedaan (panjang atau pendek) saluran pemasaran kue telur gabus di Desa Bungin Jaya Kecamatan Semendawai Timur Kabupaten OKU Timur. Hasil penelitian menunjukkan bahwa total biaya produksi usaha pengolahan kue telur gabus KWT Melati dalam satu kali proses adalah sebesar Rp 625.144, penerimaan sebesar Rp 736.900, pendapatan sebesar Rp 111.756. Nilai R/C rasio sebesar 1,18 menunjukan bahwa usaha pengolahan kue telur gabus menguntungkan. Terdapat tiga pola rantai pemasaran kue telur gabus yang melibatkan pedagang perantara dan pedagang pengecer. Keuntungan pemasaran pada saluran I adalah $100 \%$ dengan margin pemasaran sebesar Rp 0/Bks, keuntungan pemasaran saluran II sebesar 85,5\% dan 31,5\% dengan margin pemasaran sebesar Rp 300/Bks, Rp 3.000/Bks dan Rp 3.000/Bks dan keuntungn pemasaran saluran III masingmasing 100\%, 10\% dan 11\% dengan margin pemasaran masing-masing sebesar Rp 150/Bks, Rp 1.500/Bks dan Rp 1.000/Bks serta Rp 150/Bks, Rp 1.500/Bks dan Rp 4.000/Bks. Nilai farmer's share saluran pemasaran I adalah sebesar $100 \%$, saluran pemasaran II rata-rata adalah sebesar 74\%, dan saluran pemasaran III rata-rata adalah sebesar $65 \%$. Saluran pemasaran I lebih efisien daripada saluran pemasaran II dan III.
\end{abstract}

Kata Kunci : Pertanian Agribisnis, Margin Pemasaran, Analisis Pendapatan.

\section{PENDAHULUAN}

\section{A. Latar Belakang}

Agroindustri adalah industri yang mengolah hasil-hasil pertanian, mulai dari pengolahan tingkat pertama menjadi produk yang biasanya diperdagangkan, sampai dengan menjadi produk yang siap dikonsumsi oleh masyarakat. Agroindustri merupakan faktor penting dalam perekonomian sebab : (1) Agroindustri langsung berhubungan dengan kegiatan produksi untuk memenuhi kebutuhan primer umat manusia, yaitu kebutuhan akan pangan dan sandang. (2) Membuka lapangan kerja di luar usahatani. (3) Meningkatkan nilai tambah pertanian. (4) Meningkatkan penghasilan produk non-migas untuk konsumsi pasar dunia, terutama pada negara negara berkembang seperti Indonesia (Soekartawi, 2003).

Diversifikasi pangan adalah upaya peningkatan konsumsi aneka ragam pangan dengan prinsip beragam, bergizi, berimbang. Diversifikasi pangan perlu dukungan ketersediaan teknologi pengolahan yang relatif mudah dan murah untuk dapat diterapkan di masyarakat. Selain itu ketersediaan teknologi pengolahan berbagai produk pangan dari bahan lokal akan memberikan peluang bagi pertumbuhan dan pengembangan agroindustri. Hal ini diharapkan berdampak pada peningkatan nilai tambah komoditas pangan, perluasan kesempatan kerja dan peningkatan pendapatan (Wargiono, 2009).

Seiring dengan perkembangan disegala bidang, terutama bidang boga mengalami peningkatan antara lain meningkatnya produksi makanan yang sangat bervariasi dari segi bahan dasar, rasa, bentuk, dan lainlain. Hal ini mencerminkan bahwa masyarakat menginginkan variasi makanan yang bergizi tinggi, antara lain melalui konsumsi makanan dalam hal jenis, kualitas maupun kuantitasnya. Upaya peningkatan konsumsi makanan tersebut tidak hanya menitikberatkan pada makanan pokok dan lauk pauk saja tetapi juga terhadap makanan ringan. Makanan ringan atau dikenal dengan sebutan snack food adalah makanan yang dikonsumsi selain atau antara waktu makan utama dalam sehari. Oleh karena itu, makanan ini biasa disebut snack yang berarti sesuatu yang dapat mengobati rasa lapar dan memberikan suplai energi yang cukup untuk tubuh (Anonim, 2017). Salah satu bentuk kegiatan agroindustri sekaligus untuk meningkatkan nilai tambah adalah pembuatan makanan ringan yang bahan dasarnya dari tepung tapioka yaitu kue telur gabus.

Tapioka merupakan hasil olahan dari singkong atau ubi kayu yang pada pengaplikasiannya banyak digunakan sebagai bahan utama maupun bahan penolong pada pembuatan produk pangan rumah tangga maupun produk pangan industri. Tapioka mengandung amilopektin yang lebih tinggi dibandingkan dengan amilosa, 
sehingga pada pencampuran dengan air bersifat lengket. Menurut Rahman (2007), kandungan zat gizi pada tapioka sebagai berikut : kalori 307 (kalori/100 gram), lemak 0,2\%, protein 0,5-0,7\%, karbohidrat $85 \%$, air $15 \%$ dan serat $0,5 \%$.

Tabel 1. Kandungan Gizi pada Tapioka per 100 Gram Bahan.

\begin{tabular}{clcc}
\hline No & Kandungan Gizi & Satuan & Nilai $(\%)$ \\
\hline 1. & Kalori & Kal/Gram & 307 \\
2. & Protein & Gram & $0,5-0,7$ \\
3. & Lemak & Gram & 0,2 \\
4. & Karbohidrat & Gram & 85 \\
5. & Air & $\mathrm{Mg}$ & 15,00 \\
6. & Serat & $\mathrm{Mg}$ & 0,5 \\
\hline
\end{tabular}

Sumber : Rahman, 2007.

Kue telur gabus merupakan jenis makanan ringan yang memiliki ciri khas tekstur renyah, permukaan halus dan rasa yang gurih. Tapioka dan telur menjadi bahan utama dalam pembuatan kue telur gabus. Sesuai namanya, dalam pembuatan kue telur gabus menggunakan telur yang cukup banyak terutama kuningnya. Kue telur gabus memiliki rasa yang gurih sehingga banyak diminati oleh masyarakat dari segala usia. Kue telur gabus adalah makanan ringan yang dikonsumsi di luar jadwal makan utama sebagai penunda lapar (Permana, 2014).

Kelompok Wania Tani (KWT) Melati adalah salah satu unit usaha pembuatan kue telur gabus yang terletak di Desa Bungin Jaya Kecamatan Semendawai Timur Kabupaten OKU Timur. Usaha pembuatan kue telur gabus ini telah dimulai sejak Bulan Agustus 2019. KWT Melati dalam menjalankan kegiatan usahanya telah menerapkan berbagai strategi bauran pemasaran yang meliputi strategi produk, harga, distribusi, dan promosi.

Berdasarkan survei pendahuluan terhadap KWT Melati, diperoleh bahwa strategi produk yang diterapkan yaitu mengembangkan produk kue telur gabus dengan berbagai variasi rasa seperti telur gabus rasa balado, rasa jagung manis, dan rasa original, menjaga kualitas produk, serta menetapkan logo dalam kemasan. Adapun strategi harga yang diterapkan yaitu menetapkan harga jual yang terjangkau sesuai pasar serta kualitas produk yang bagus. Sedangkan strategi distribusi yaitu dengan memfokuskan penjualan pada daerah sendiri kemudian memperluasnya ke daerah lain serta strategi promosi yang diterapkan yaitu adanya potongan harga serta periklanan melalui media sosial.

Pemasaran kue telur gabus KWT Melati melibatkan tiga lembaga (produsen, lembaga pemasaran dan konsumen) yang memiliki kepentingan yang berbeda. KWT Melati sebagai produsen selalu menginginkan pendapatan yang lebih baik, sedangkan lembaga pemasaran mengharapkan keuntungan yang tinggi serta konsumen akhir menginginkan harga yang relatif rendah.

\section{B. Rumusan Masalah}

Berdasarkan latar belakang dan uraian di atas, adapun permasalahan yang menarik untuk diteliti adalah sebagai berikut :

1. Berapa besar pendapatan usaha pengolahan kue telur gabus oleh KWT Melati di Desa Bungin Jaya Kecamatan Semendawai Timur Kabupaten OKU Timur?

2. Bagaimana pola rantai pemasaran kue telur gabus oleh KWT Melati di Desa Bungin Jaya Kecamatan Semendawai Timur Kabupaten OKU Timur?

3. Berapa besar keuntungan dan margin pemasaran kue telur gabus pada setiap lembaga pemasaran oleh KWT Melati di Desa Bungin Jaya Kecamatan Semendawai Timur Kabupaten OKU Timur?

4. Apakah terdapat perbedaan nilai bagian yang diterima (farmer's share) KWT Melati karena perbedaan (panjang atau pendek) saluran pemasaran kue telur gabus di Desa Bungin Jaya Kecamatan Semendawai Timur Kabupaten OKU Timur?

\section{Tujuan dan Kegunaan}

Berdasarkan rumusan masalah yang telah dijabarkan, maka secara umum penelitian ini bertujuan untuk :

1. Mengetahui besar pendapatan usaha pengolahan kue telur gabus oleh KWT Melati di Desa Bungin Jaya Kecamatan Semendawai Timur Kabupaten OKU Timur.

2. Mengetahui pola rantai pemasaran kue telur gabus oleh KWT Melati di Desa Bungin Jaya Kecamatan Semendawai Timur Kabupaten OKU Timur.

3. Mengetahui keuntungan dan margin pemasaran kue telur gabus pada setiap saluran pemasaran oleh KWT Melati di Desa Bungin Jaya Kecamatan Semendawai Timur Kabupaten OKU Timur.

4. Mengetahui perbedaan nilai bagian yang diterima (farmer's share) KWT Melati karena perbedaan (panjang atau pendek) saluran pemasaran kue telur gabus di Desa Bungin Jaya Kecamatan Semendawai Timur Kabupaten OKU Timur.

Hasil penelitian ini diharapkan menjadi bahan informasi informasi untuk menambah wawasan dan pengetahuan, khususnya meningkatkan pemasaran produk olahan kue telur gabus di Kabupaten OKU Timur. Selain itu, hasil ini juga diharapkan dapat menjadi bahan referensi untuk penelitian selanjutnya dan sebagai pustaka ilmiah

\section{KERANGKA PEMIKIRAN}

\section{A. Model Pendekatan}


Model pendekatan yang digunakan dalam penelitian ini adalah model pendekatan secara diagramatis.

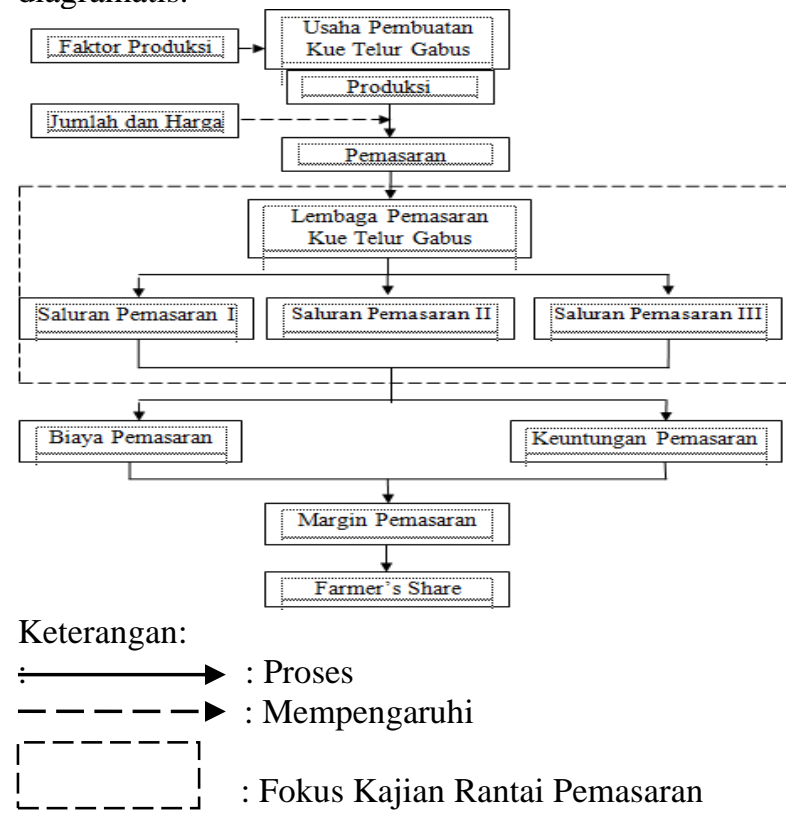

Gambar1 : Model Pendekatan Diagramatis Pemasaran Kue Telur Gabus pada KWT Melati di Desa Bungin Jaya Kecamatan Semendawai Timur Kabupaten OKU Timur.

\section{B. Hipotesis}

Berdasarkan tujuan penelitian di atas, maka dapat ditarik suatu hipotesis dalam penelitian ini adalah sebagai berikut:

1. Diduga bahwa penerimaan lebih besar daripada biaya produksi sehingga diperoleh pendapatan usaha pengolahan kue telur gabus KWT Melati di Desa Bungin Jaya Kecamatan Semendawai Timur Kabupaten OKU Timur.

2. Diduga bahwa pola pemasaran kue telur gabus pada KWT Melati di Desa Bungin Jaya Kecamatan Semendawai Timur Kabupaten OKU Timur terdiri atas tiga saluran pemasaran.

3. Diduga bahwa terdapat keuntungan dan selisih harga atau margin pemasaran kue telur gabus pada setiap lembaga pemasaran pada KWT Melati di Desa Bungin Jaya Kecamatan Semendawai Timur Kabupaten OKU Timur.

4. Diduga bahwa terdapat perbedaan nilai bagian yang diterima (farmer's share) karena perbedaan (panjang atau pendek) saluran pemasaran kue telur gabus pada KWT Melati di Desa Bungin Jaya Kecamatan Semendawai Timur Kabupaten OKU Timur.

\section{Batasan-Batasan}

1. Kue telur gabus adalah sejenis makanan ringan (snek) dengan ciri khas teksturnya renyah, bentuknya bulat lonjong, bagian dalam tidak berlubang, dan rasanya yang gurih dan telah melalui tahap penggorengan.

2. Produksi adalah banyaknya kue telur gabus yang dihasilkan dalam satu kali proses produksi (Kg/Proses).

3. Proses produksi adalah waktu yang dibutuhkan dalam mengolah kue telur gabus yaitu rata-rata selama 5 hari.

4. Harga adalah harga jual kue telur gabus pada saat penelitian $(\mathrm{Rp} / \mathrm{Kg})$.

5. Biaya tetap adalah biaya yang besarnya tidak dipengaruhi oleh jumlah produksi dan tidak habis dalam satu kali proses produksi, meliputi biaya penyusutan peralatan dan biaya sewa tempat (Rp/Proses).

6. Biaya variabel adalah biaya yang dipengaruhi besar kecilnya produksi dan habis dalam satu kali proses, meliputi biaya bahan baku dan tenaga kerja (Rp/Proses).

7. Biaya total adalah semua biaya yang digunakan dalam usaha pembuatan kue telur gabus, meliputi biaya tetap ditambah biaya variabel (Rp/Proses).

8. Penerimaan usaha adalah perkalian antara produksi kue telur gabus yang terjual dengan harga jual kue telur gabus (Rp/Proses).

9. Pendapatan adalah selisih antara total penerimaan dengan biaya total usaha pembuatan kue telur gabus (Rp/Proses).

10. Pemasaran adalah suatu kegiatan yang dilakukan dengan memasarkan suatu produk barang atau jasa antara produsen dan konsumen.

11. Saluran Pemasaran adalah saluran yang digunakan oleh lembaga pemasaran untuk menyalurkan komoditi kue telur gabus dari titik produsen sampai ke titik konsumen yang membentuk pola pemasaran.

12. Lembaga pemasaran adalah lembaga-lembaga yang melaksanakan fungsi-fungsi pemasaran melalui proses pendistribusian kue telur gabus dari produsen ke konsumen.

13. Pedagang pengecer adalah pedagang yang membeli atau memasarkan kue telur gabus dari lembaga sebelumnya kemudian menjualnya langsung ke konsumen.

14. Konsumen adalah orang yang membeli kue telur gabus untuk dikonsumsi sesuai dengan tingkat kebutuhannya.

15. Biaya pemasaran adalah biaya yang dikeluarkan secara langsung oleh lembaga pemasaran untuk kegiatan pemasaran kue telur gabus. Biaya dihitung dengan merata-ratakan seluruh biaya yang dikeluarkan oleh setiap lembaga pemasaran. Satuan yang digunakan adalah rupiah per $\mathrm{kg}$ $(\mathrm{Rp} / \mathrm{Kg})$.

16. Keuntungan pemasaran adalah selisih antara harga jual dengan harga beli dan biaya pemasaran yang diterima suatu lembaga pemasaran (Rp).

17. Margin pemasaran adalah perbedaan harga suatu barang yang diterima produsen dengan harga yang dibayarkan oleh konsumen akhir. Margin 
pemasaran diukur dengan membandingkan harga kue telur gabus ditingkat konsumen dengan harga kue telur gabus ditingkat produsen $(\mathrm{Rp} / \mathrm{Kg})$.

18. Farmer's share adalah perbandingan harga yang diterima oleh produsen dengan harga yang dibayar oleh konsumen akhir dikalikan 100\%. Farmer's share merupakan indikator untuk mengetahui efisiensi pemasaran. (\%)

\section{PELAKSANAAN PENELITIAN}

\section{A. Tempat dan Waktu}

Penelitian ini akan dilaksanakan di Desa Bungin Jaya Kecamatan Semendawai Timur Kabupaten OKU Timur. Pemilihan lokasi dilakukan secara sengaja (purposive) dengan pertimbangan bahwa di desa tersebut terdapat industri rumah tangga yang mengolah kue telur gabus yang tergabung dalam Kelompok Wanita Tani (KWT) Melati. Penelitian ini akan dilaksanakan pada Bulan Maret 2020.

\section{B. Metode Penelitian dan Penarikan Contoh}

Metode penelitian yang digunakan dalam penelitian ini adalah metode studi kasus (case study) yang bertujuan memperoleh gambaran yang lebih mendalam dari suatu objek yang diteliti. Menurut Nazir (2005), studi kasus adalah penelitian tentang kasus subyek penelitian yang berkenaan dengan suatu fase spesifik atau khas dari keseluruhan personalitas. Subjek penelitian dapat berupa individu, kelompok, lembaga maupun masyarakat. Tujuan studi kasus adalah untuk memberikan gambaran secara detail tentang latar belakang, sifat-sifat serta karakterkarakter yang khas dari kasus atau pun status individu yang kemudian dari sifat-sifat tersebut akan dijadikan suatu hal yang bersifat umum. Penelitian dilakukan dengan mengumpulkan data yang hasilnya dianalisis secara deskriptif untuk mencari dan mengetahui saluran serta margin pemasaran pada usaha pengolahan kue telur gabus.

Sedangkan metode penarikan contoh yang digunakan dalam penelitian ini adalah dengan menggunakan teknik snowball. Cara pengambilan sampel dengan teknik ini dilakukan secara berantai. Pelaksanaannya pertama-tama melakukan interview terhadap KWT Melati sebagai pelaku usaha pengolahan kue telur gabus di Desa Bungin Jaya, selanjutnya yang bersangkutan diminta untuk menyebutkan calon responden lainnya seperti toko atau warung, pedagang pengecer serta pedagang perantara.

Tabel 2. Responden Penelitian Lembaga Pemasaran Kue Telur Gabus KWT Melati di Desa Bungin Jaya Kecamatan Semendawai Timur, 2020.

\begin{tabular}{cccc}
\hline No & Lembaga Pemasaran & $\begin{array}{c}\text { Jumlah } \\
\text { Populasi } \\
\text { (Jiwa) }\end{array}$ & $\begin{array}{c}\text { Jumlah } \\
\text { Sampel } \\
\text { (Jiwa) }\end{array}$ \\
\hline 1. & Pedagang Perantara & 2 & 2 \\
2. & Pedagang Pengecer & 12 & 12 \\
\hline
\end{tabular}

\begin{tabular}{ccc}
\hline Jumlah & 14 & 14 \\
\hline Sumber : Data Primer, 2020.
\end{tabular}

Sumber : Data Primer, 2020.

\section{Metode Pengolahan dan Analisis Data}

Untuk menjawab tujuan penelitian yang pertama yaitu untuk mengetahui pendapatan usaha pengolahan kue telur gabus KWT Melati di Desa Bungin Jaya Kecamatan Semendawai Timur OKU Timur maka dihitung dengan rumus :

1. Untuk menghitung biaya produksi digunakan rumus (Soekartawi, 2002) :

$\mathrm{TC}=\mathrm{FC}+\mathrm{VC}$

$\mathrm{TC}=$ Total Cost/Total Biaya Produksi (Rp/Proses)

$\mathrm{FC}=$ Fixed Cost $/$ Biaya Tetap (Rp/Proses)

$\mathrm{VC}=$ Variable Cost/Biaya Variabel (Rp/Proses)

2. Untuk menghitung penerimaan, digunakan rumus (Soekartawi, 2002) :

$\mathrm{TR}=\mathrm{Py} \times \mathrm{Y}$.....

$\mathrm{TR}=$ Total Revenues/Penerimaan (Rp/Proses)

$\mathrm{Py}=$ Price Yield/Harga Jual Produk $(\mathrm{Rp} / \mathrm{Kg})$

$\mathrm{Y}=$ Yield $/$ Hasil produksi (Kg/Proses)

3. Untuk menghitung pendapatan, digunakan rumus (Suratiyah, 2006) :

$\mathrm{I}=\mathrm{TR}-\mathrm{TC}$.

$\mathrm{I}=$ Income/Pendapatan $(\mathrm{Rp} / \mathrm{Proses})$

$\mathrm{TR}=$ Total Revenue/Penerimaan (Rp/Proses)

$\mathrm{TC}=$ Total Cost/Total Biaya Produksi (Rp/Proses)

Untuk menjawab tujuan penelitian yang kedua yaitu untuk mengetahui rantai atau pola saluran pemasaran kue telur gabus KWT Melati di Desa Bungin Jaya Kecamatan Semendawai Timur Kabupaten OKU Timur maka digunakan metode deskriftif dan dianalisis secara kualitatif.

Untuk menjawab tujuan penelitian yang ketiga yaitu untuk mengetahui margin pemasaran kue telur gabus pada setiap lembaga pemasaran maka digunakan rumus sebagai berikut : (Ibrahim, 2009).

a. Menghitung besarnya margin pemasaran yang diterima pada setiap masing- masing saluran pemasaran, digunakan rumus yaitu :

$\mathrm{Mpi}=\mathrm{Hji}-\mathrm{Hbi}$

Dimana :

Mpi = Margin pemasaran ke-i $(\mathrm{Rp} / \mathrm{Kg})$

$\mathrm{Hji}=$ Harga jual ke-i $(\mathrm{Rp} / \mathrm{Kg})$

$\mathrm{Hbi}=$ Harga beli ke-i $(\mathrm{Rp} / \mathrm{Kg})$

$\mathrm{i}=$ Lembaga pemasaran

b.Menghitung keuntungan pada masing-masing lembaga pemasaran, digunakan rumus yaitu :

$\mathrm{Kpi}=\mathrm{Mpi}-\mathrm{Bpi}$

$\mathrm{Bpi}=\mathrm{T}+\mathrm{TK}+\mathrm{S}-\mathrm{P}+\mathrm{R}+\mathrm{L}$

Dimana :

$\mathrm{Kpi}=$ Keuntungan pemasaran $(\mathrm{Rp} / \mathrm{Kg})$

$\mathrm{Bpi}=$ Biaya pemasaran $(\mathrm{Rp} / \mathrm{Kg})$

$\mathrm{T}=$ Biaya transportasi $(\mathrm{Rp} / \mathrm{Kg})$

$\mathrm{TK}=$ Tenaga kerja (Rp)

$\mathrm{S}=$ Penyusutan $(\mathrm{Rp})$

$\mathrm{P}=$ Biaya Pengemasan $(\mathrm{Rp})$

$\mathrm{R}=$ Retribusi $(\mathrm{Rp})$ 
ISSN : 2598-0521

$\mathrm{L}=$ Biaya lainya, seperti biaya telpon dan lainya.

Untuk menjawab tujuan penelitian yang keempat yaitu untuk menghitung besarnya farmer's share yang diterima KWT Melati di Desa Bungin Jaya Kecamatan Semendawai Timur Kabupaten OKU Timur maka dihitung dengan menggunakan rumus sebagai berikut (Nasruddin, 2006) :

$$
\text { If }=\frac{P f}{P r} x 100 \%
$$

Dimana :

If = Farmer's share $(\%)$

$\mathrm{P} f=$ Harga ditingkat produsen $(\mathrm{Rp} / \mathrm{Kg})$

$\mathrm{Pr}=$ Harga ditingkat konsumen $(\mathrm{Rp} / \mathrm{Kg})$

\section{HASIL DAN PEMBAHASAN}

\section{A. Analisis Biaya Usaha Pembuatan Kue Telur Gabus}

Analisa usaha digunakan sebagai tolak ukur suatu usaha apakah menguntungkan atau tidak dan apakah usaha tersebut layak untuk dikembangkan atau tidak. Biaya dalam kegiatan usaha dikeluarkan oleh pelaku usaha dengan tujuan untuk menghasilkan pendapatan yang tinggi bagi usaha yang dikerjakan, dengan mengeluarkan biaya maka pelaku usaha mengharapkan pendapatan yang setinggi-tingginya melalui peningkatan produksi. Biaya dalam kegiatan usaha terdiri dari biaya tetap (fixed cost), biaya variabel (variabel cost) dan biaya total (total cost).

\section{Biaya Tetap (Fixed Cost)}

Biaya tetap (fixed cost) adalah biaya yang relatif tetap jumlahnya dan harus dikeluarkan walaupun produk yang dihasilkan banyak atau sedikit. Dalam hasil penelitian yang dikelompokkan ke dalam biaya tetap di antaranya adalah biaya sewa tempat dan biaya penyusutan alat.

$$
\begin{aligned}
\text { FC } & =\text { Sewa Tempat }+ \text { Penyusutan Alat } \\
& =27.778+16.371 \\
& =44.149
\end{aligned}
$$

Tabel 3. Biaya Tetap Usaha Pembuatan Kue Telur Gabus KWT Melati, 2020.

\begin{tabular}{llcc}
\hline & & \multicolumn{2}{c}{ Nilai } \\
\cline { 3 - 4 } No & Komponen Biaya & $($ Rp/Bulan $)$ & $($ Rp/Proses $)$ \\
\hline 1. & Sewa Tempat Usaha & $\mathbf{1 6 6 . 6 6 7}$ & $\mathbf{2 7 . 7 7 8}$ \\
2. & Penyusutan Alat & $\mathbf{9 8 . 2 2 5}$ & $\mathbf{1 6 . 3 7 1}$ \\
& & & \\
& a. Mixer & 13.368 & 2.228 \\
& b. Kompor Gas & 6.489 & 1.081 \\
& c. Baskom & 4.375 & 729 \\
d. Wajan & 13.750 & 2.292 \\
e. Toples & 10.000 & 1.667 \\
f. Timbangan & 9.549 & 1.591 \\
g. Ember Plastik & &
\end{tabular}

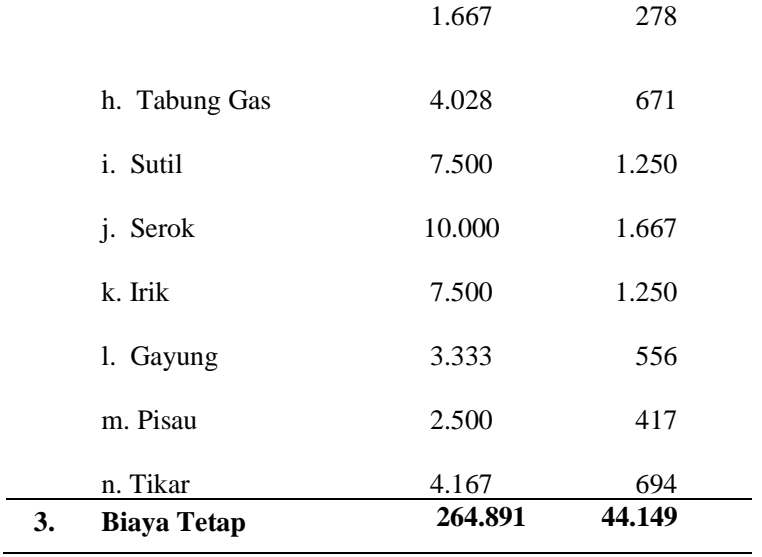

Sumber : Data Primer, 2020.

Bahwa biaya sewa tempat usaha pembuatan kue telur gabus KWT Melati, dalam satu kali proses produksi (5 hari) adalah sebesar Rp 27.778 atau sebesar Rp 166.667/Bulan. Adapun rata-rata biaya penyusutan alat yang digunakan dalam satu kali proses produksi adalah sebesar Rp 16.371 atau sebesar Rp 98.225/Bulan. Biaya tetap usaha pembuatan kue telur gabus KWT Melati yang terdiri dari biaya sewa lahan dan biaya penyusutan peralatan dalam satu kali proses produksi adalah sebesar Rp 44.149 atau rata-rata sebesar Rp 264.891/Bulan.

2. Biaya Variabel (Variable Cost)

Biaya variabel adalah biaya besar kecilnya tergantung dari banyak atau sedikitnya produksi yang dihasilkan dan biasanya habis dalam satu kali proses produksi. Biaya variabel yang digunakan dalam usaha pembuatan kue telur gabus KWT Melati di Desa Bungin Jaya Kecamatan Semendawai Timur Kabupaten OKU Timur terdiri atas biaya pembelian bahan baku dan biaya tenaga kerja.

$\mathrm{VC}=$ Biaya Bahn Baku + Biaya Tenaga Kerja

$=396.829+184.167$

$=580.996$

Tabel 4. Biaya Variabel Usaha Pembuatan Kue Telur Gabus KWT Melati, 2020.

\begin{tabular}{llc}
\hline No & Komponen Biaya & Nilai (Rp/Proses) \\
\hline 1. & Biaya Bahan Baku & $\mathbf{3 9 6 . 8 2 9}$ \\
& a. Tepung Tapioka & 83.936 \\
b.Telur & 56.063 \\
c. Margarin & 44.294 \\
d.Minyak Goreng & 81.944 \\
e.Penyedap Rasa & 11.167 \\
f. Bumbu Balado & 23.333 \\
g.Lilin & 8.667 \\
h.Label & 40.250 \\
i. Gas Elpiji & 28.000 \\
j. Plastik 0,2 Kg & 12.667 \\
k.Plastik 0,5 Kg & 4.842 \\
1. Plastik 1 Kg & 1.667 \\
\end{tabular}




\begin{tabular}{rlr} 
2. & Biaya Tenaga Kerja & 184.167 \\
\hline 3. & Biaya Variabel & 580.996
\end{tabular}

Sumber : Data Primer, 2020.

Berdasarkan hasil tabel 4, diketahui bahwa ratarata besarnya biaya pembelian bahan baku diantaranya untuk membeli tepung tapioka, telur, margarin, minyak goreng, penyedap rasa, bumbu, gas elpiji, lilin, label dan plastik dalam satu kali proses produksi rata-rata adalah sebesar Rp 396.829. Upah tenaga kerja dibayarkan secara borongan dengan besar upah $\mathrm{Rp}$ $10.000 / \mathrm{Kg}$ kue telur gabus. Besarnya biaya tenaga kerja pembuatan kue telur gabus dalam satu kali proses rata-rata adalah sebesar Rp 184.167. Besarnya biaya variabel usaha pembuatan kue telur gabus yang terdiri dari biaya bahan baku dan biaya tenaga kerja dalam satu kali proses produksi rata-rata adalah sebesar $\mathrm{Rp}$ 580.996.

\section{Biaya Total (Total Cost)}

Biaya total dalam kegiatan usaha pembuatan kue telur gabus KWT Melati terdiri dari biaya tetap ditambah dengan biaya variabel. Biaya produksi usahatani dapat dihitung dengan rumus sebagai berikut :

$$
\begin{aligned}
\mathrm{TC} & =\mathrm{FC}+\mathrm{VC} \\
& =44.149+580.996 \\
& =\mathbf{6 2 5 . 1 4 4}
\end{aligned}
$$

Bahwa biaya tetap usaha pembuatan kue telur gabus KWT Melati yang terdiri dari biaya sewa tempat dan biaya penyusutan peralatan dalam satu kali proses produksi (5 hari) rata-rata adalah sebesar Rp 44.149. Biaya variabel yang terdiri dari biaya bahan baku dan biaya tenaga kerja dalam satu kali proses produksi ratarata adalah sebesar $\mathrm{Rp} 580.996$, sehingga diperoleh total biaya produksi usaha pembuatan kue telur gabus KWT Melati yang terdiri biaya tetap dan biaya variabel dalam satu kali proses produksi adalah sebesar Rp 625.144 .

Tabel 5. Total Biaya Produksi Usaha Pembuatan Kue Telur Gabus KWT Melati, 2020.

\begin{tabular}{lll}
\hline No & Komponen Biaya & Nilai (Rp/Proses) \\
\hline 1. & Biaya Tetap & 27.778 \\
& a. Sewa Tempat & 16.371 \\
& b. Penyusutan Peralatan & $\mathbf{4 4 . 1 4 9}$ \\
& c. Jumlah Biaya Tetap & \\
2. $\quad$ Biaya Variabel & 396.829 \\
& a. Biaya Bahan Baku & 184.167 \\
& b. Biaya Tenaga Kerja & $\mathbf{5 8 0 . 9 9 6}$ \\
& c. Jumlah Biaya Variabel & $\mathbf{6 2 5 . 1 4 4}$ \\
\hline 3. & Total Biaya Produksi & \\
\hline
\end{tabular}

Sumber : Data Primer, 2020.

\section{Produksi, Harga, Penerimaan dan Pendapatan}

Hasil akhir atau produksi dalam usaha pembuatan kue telur gabus adalah berupa kue telur gabus yang terdiri dari dua varian rasa yaitu rasa pedas (balado) dan original. Proses pembuatan kue telur gabus dari awal sampai dengan proses pengemasan dikerjakan secara bersama-sama diantara anggota KWT Melati. Kue telur gabus yang dihasilkan oleh KWT Melati terdiri dari tiga kemasan yaitu kemasan 10 gram, kemasan 100 gram dan kemasan 200 gram.

Rata-rata produksi kue telur gabus dalam satu kali proses adalah sebanyak $13 \mathrm{Kg}$ yang terdiri dari kue telur gabus kemasan 10 gram sebanyak 317 bungkus (3 $\mathrm{Kg}$ ) dengan harga jual Rp 700/Bks, kemasan 200 gram sebanyak 69 bungkus (7 Kg) dengan harga jual Rp 5.000/Bks dan kemasan 200 gram sebanyak 17 bungkus $(3 \mathrm{Kg}$ ) dengan harga jual Rp 10.000/Bks. Adapun penerimaan usaha dalam satu kali proses ratarata adalah sebesar $\mathrm{Rp} 736.900$. Rata-rata total biaya produksi usaha pembuatan kue telur gabus dalam satu kali proses adalah sebesar Rp 625.144 sehingga pendapatan usaha pembuatan kue telur gabus KWT Melati dalam satu kali proses produksi rata-rata adalah sebesar Rp 111.756.

Tabel 6. Produksi, Harga, Penerimaan dan Pendapatan

\begin{tabular}{|c|c|c|c|}
\hline No & Uraian & Satuan & Nilai \\
\hline 1. & $\begin{array}{l}\text { Produksi Kue Telur Gabus } \\
\text { a. Kemasan } 10 \text { Gram } \\
\text { b. Kemasan } 100 \text { Gram } \\
\text { c. Kemasan } 200 \text { Gram }\end{array}$ & $\begin{array}{l}\text { Bungkus/Proses } \\
\text { Bungkus/Proses } \\
\text { Bungkus/Proses }\end{array}$ & $\begin{array}{c}317 \\
69 \\
17\end{array}$ \\
\hline 2. & $\begin{array}{l}\text { Harga } \\
\text { a. Kemasan } 10 \text { Gram } \\
\text { b. Kemasan } 100 \text { Gram } \\
\text { c. Kemasan } 200 \text { Gram }\end{array}$ & $\begin{array}{l}\text { Rp/Bungkus } \\
\text { Rp/Bungkus } \\
\text { Rp/Bungkus }\end{array}$ & $\begin{array}{c}700 \\
5.000 \\
10.000\end{array}$ \\
\hline 3. & Penerimaan & Rp/Proses & 736.900 \\
\hline 4. & Total Biaya Produksi & Rp/Proses & 625.144 \\
\hline 5. & Pendapatan & Rp/Proses & 111.756 \\
\hline 6. & R/C Rasio & & 1,18 \\
\hline
\end{tabular}
Usaha Pembuatan Kue Telur Gabus KWT Melati, 2020.

Sumber : Data Primer, 2020.

Analisis R/C rasio dapat digunakan untuk mengetahui rasio tingkat keuntungan suatu usaha yang dijalankan. Berdasarkan hasil perhitungan pada Tabel 12 diperoleh bahwa nilai $\mathrm{R} / \mathrm{C}$ rasio usaha pembuatan kue telur gabus KWT Melati adalah sebesar 1,18. Nilai $\mathrm{R} / \mathrm{C}$ rasio sebesar 1,18 artinya bahwa setiap satu rupiah biaya yang dikeluarkan untuk usaha pembuatan kue telur gabus maka akan menghasilkan penerimaan sebesar Rp 1,18 dan akan menghasilkan pendapatan sebesar Rp 0,18. Karena perhitungan nilai R/C > 1, ini menunjukkan bahwa usaha pembuatan kue telur gabus KWT Melati di Desa Bungin Jaya menguntungkan.

\section{B. Rantai Pemasaran Kue Telur Gabus}

Tataniaga atau pemasaran secara umum yaitu sebagai suatu kegiatan ekonomi yang memiliki fungsi untuk menyampaikan atau membawa barang maupun jasa dari produsen hingga konsumen. Proses kegiatan 
menyaluran barang-barang tersebut memerlukan berbagai fungsi tataniaga. Pemasaran bertujuan untuk menyalurkan barang dan jasa dari produsen kepada konsumen

Proses pemasaran kue telur gabus bertujuan untuk menyalurkan produk telur gabus dari produsen dalam hal ini adalah KWT Melati sampai ke konsumen. Kue telur gabus yang diproduksi oleh KWT Melati terdiri dari dua varian rasa yaitu rasa pedas (balado) dan original dengan tiga macam kemasan yaitu kue telur gabus kemasan 10 gram dengan harga jual Rp 700/Bks, kemasan 100 gram dengan harga jual Rp 5.000/Bks dan kemasan 200 gram dengan harga jual Rp 10.000/Bks.

Untuk proses produksi pengolahan kue telur gabus KWT Melati masih menggunakan alat-alat produksi yang masih sederhana sehingga kapasitas produksi yang dihasilkan juga masih terbatas. Kendala utama yang dihadapi oleh KWT Melati adalah keterbatasan modal. KWT Melati berharap ada dukungan dan bantuan pemerintah melalui instansi atau dinas terkait. Adapun bantuan yang diharapkan terutama adalah bantuan berupa alat-alat atau mesin produksi yang dapat mendukung proses pembuatan kue telur gabus. KWT Melati berharap dengan adanya bantuan pemerintah ini maka usaha pembuatan kue telur gabus KWT Melati ini semakin berkembang dan maju.

Dari hasil wawancara yang dilakukan dengan KWT Melati di dalam proses pemasaran kue telur gabus maka terdapat tiga lembaga pemasaran yang terlibat di dalam proses pemasaran kue telur gabus diantaranya adalah produsen, pedagang perantara dan pedagang pengecer. Pada lembaga-lembaga pemasaran ini terdapat tiga model saluran pemasaran yaitu :

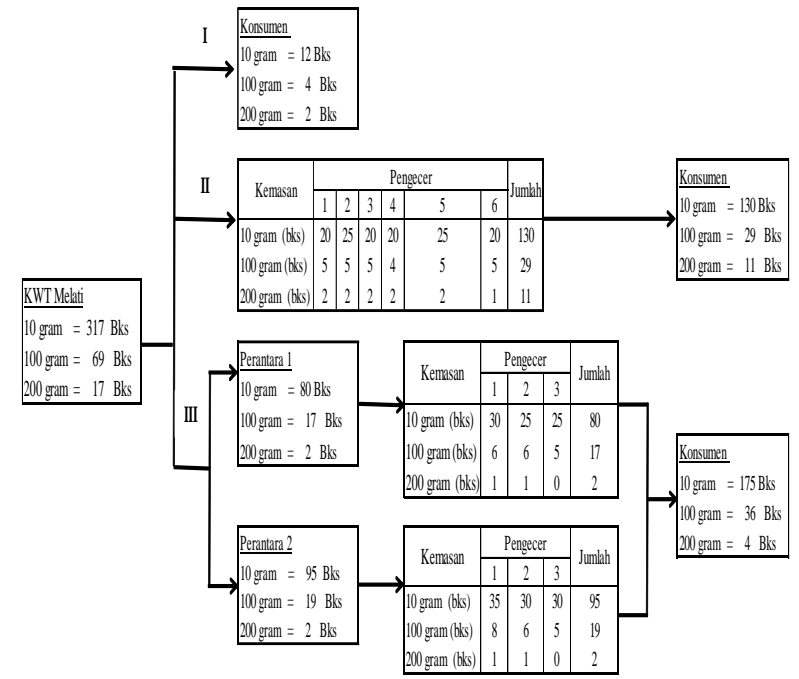

Gambar 2 : Pemasaran Kue Telur Gabus KWT Melati Kabupaten OKU Timur.

Pada gambar saluran pemasaran di atas, terdapat tiga model pemasaran yang dapat dijelaskan sebagai berikut :

\section{Saluran Pemasaran I}

Pada model saluran pemasaran pertama aliran kue telur gabus mulai dari produsen (KWT Melati) langsung dijual kepada konsumen. Konsumen disini pada umumnya adalah tetangga yang berada di sekitar tempat pembuatan kue telur gabus KWT Melati. Ratarata terdapat 5 orang konsumen yang langsung membeli kue telur gabus di KWT Melati dalam setiap kali proses produksi.

Kue telur gabus yang langsung dibeli oleh konsumen terdiri dari tiga macam kemasan yaitu :

1). Kue telur gabus kemasan 10 gram yang dijual dengan harga Rp 700/Bks. Banyaknya kue telur gabus kemasan ini yang dibeli oleh konsumen dalam setiap kali proses produksi rata-rata adalah sebanyak 12 bungkus sehingga total nilai penjualan KWT Melati adalah sebesar Rp 8.400.

2). Kue telur gabus kemasan 100 gram yang dijual dengan harga $\mathrm{Rp}$ 5.000/Bks. Banyaknya kue telur gabus kemasan ini yang dibeli oleh konsumen dalam setiap kali proses produksi rata-rata adalah sebanyak 4 bungkus sehingga total nilai penjualan KWT Melati adalah sebesar Rp 20.000.

3). Kue telur gabus kemasan 200 gram yang dijual dengan harga Rp 10.000/Bks. Banyaknya kue telur gabus kemasan ini yang dibeli oleh konsumen dalam setiap kali proses produksi rata-rata adalah sebanyak 2 bungkus sehingga total nilai penjualan KWT Melati adalah sebesar $\quad \mathrm{Rp} 20.000$. Adapun total nilai penjualan kue telur gabus yang dijual oleh KWT Melati kepada konsumen dalam setiap kali proses produksi rata-rata adalah sebesar Rp 48.400 .

\section{Saluran Pemasaran II}

Pada model saluran pemasaran kedua ini aliran kue telur gabus mulai dari produsen (KWT Melati) disalurkan kepada pedagang pengecer. Pedagang pengecer disini adalah berupa toko atau warung makanan yang berada di wilayah Desa Bungin Jaya maupun sekitar wilayah Kecamatan Semendawai Timur. Pada umumnya warung atau toko ini berada sekitar pasar atau di lokasi yang strategis dan mudah terjangkau oleh konsumen. KWT Melati menitipkan kue telur gabus di warung atau toko tersebut. Terdapat 6 (enam) buah warung atau toko yang bekerjasama dengan KWT Melati dalam memasarkan kue telur gabus. Warung atau toko tersebut kemudian langsung menjual kue telur gabus kepada konsumen. Setiap lima hari sekali KWT Melati mengantarkan kue telur gabus tersebut untuk dititipkan dan dijual kepada konsumen.

Pada saluran pemasaran kedua ini KWT Melati mengeluarkan biaya pemasaran untuk jasa kurir sebesar Rp 50.000. Kue telur gabus yang disalurkan oleh KWT Melati kepada Pedagang pengecer terdiri dari tiga macam kemasan yaitu :

1). Kue telur gabus kemasan 10 gram dengan harga jual rata-rata Rp 700/Bks. Banyaknya kue telur gabus kemasan ini yang disalurkan KWT Melati kepada pedagang pengecer dalam setiap kali proses produksi rata-rata adalah sebanyak 130 bungkus sehingga total nilai penjualan KWT Melati adalah sebesar Rp 91.000. Oleh pedagang pengecer kue telur gabus kemasan ini kemudian dijual kepada konsumen seharga Rp 
1.000/Bks sehingga diperoleh nilai penjualan pedagang pengecer sebesar Rp 130.000.

2). Kemasan 100 gram dengan harga jual Rp 5.000/Bks yang kemudian dijual oleh pedagang pengecer kepada konsumen seharga Rp 8.000/Bks. Banyaknya kue telur gabus kemasan ini yang disalurkan KWT Melati kepada pedagang pengecer dalam setiap kali proses produksi rata-rata adalah sebanyak 29 bungkus sehingga total nilai penjualan KWT Melati adalah sebesar Rp 145.000. Oleh pedagang pengecer kue telur gabus kemasan ini kemudian dijual kepada konsumen seharga $\mathrm{Rp}$ 8.000/Bks sehingga diperoleh nilai penjualan pedagang pengecer sebesar Rp 232.000.

3). Kemasan 200 gram dengan harga jual $\mathrm{Rp}$ 10.000/Bks yang kemudian dijual oleh pedagang pengecer kepada konsumen seharga Rp 13.000/Bks Banyaknya kue telur gabus kemasan ini yang disalurkan KWT Melati kepada pedagang pengecer dalam setiap kali proses produksi rata-rata adalah sebanyak 11 bungkus sehingga total nilai penjualan KWT Melati adalah sebesar Rp 110.000. Oleh pedagang pengecer kue telur gabus kemasan 200 gram ini dijual kepada konsumen seharga Rp 13.000/Bks sehingga diperoleh nilai penjualan pedagang pengecer sebesar Rp 143.000.

Dalam saluran pemasaran kedua ini, pedagang pengecer tidak mengeluarkan biaya pemasaran seperti biaya transportasi, dan retribusi, maupun lainnya karena barang dagangan langsung diantarkan oleh pihak produsen. Pedagang pengecer hanya mengeluarkan biaya untuk sewa dan tenaga kerja saja. Kue telur gabus yang dijual oleh pedagang pengecer apabila tidak habis terjual maka pedagang perantara tidak menanggung resiko kerugian, karena barang akan dikembalian kepada KWT Melati.

Tabel 7. Fungsi Tataniaga Setiap Lembaga Pemasaran pada Saluran II.

\begin{tabular}{|c|c|c|c|}
\hline No & Fungsi Tataniaga & Produsen & $\begin{array}{l}\text { Pedagang } \\
\text { Pengecer }\end{array}$ \\
\hline \multirow[t]{3}{*}{1.} & Fungsi Pertukaran & & \\
\hline & Penjualan & $\sqrt{ }$ & $\sqrt{ }$ \\
\hline & Pembelian & - & $\sqrt{ }$ \\
\hline \multirow[t]{4}{*}{2.} & Fungsi Fisik & & \\
\hline & Pengangkutan & $\sqrt{ }$ & - \\
\hline & Penyimpanan & - & $\sqrt{ }$ \\
\hline & Pengemasan & $\sqrt{ }$ & - \\
\hline \multirow[t]{5}{*}{3.} & Fungsi Fasilitas & & \\
\hline & Sortasi/Grading & $\sqrt{ }$ & - \\
\hline & Penanggungan Resiko & $\sqrt{ }$ & - \\
\hline & Pembiayaan & $\sqrt{ }$ & - \\
\hline & Informasi Harga & $\sqrt{ }$ & - \\
\hline
\end{tabular}

Sumber : Data Primer, 2020.

\section{Saluran Pemasaran III}

Pada model saluran pemasaran ketiga ini aliran kue telur gabus mulai dari produsen (KWT Melati) dijual atau disalurkan kepada pedagang perantara yang kemudian oleh pedagang perantara disalurkan kepada pedagang pengecer dan oleh pedagang pengecer kemudian langsung dijual kepada konsumen. Pedagang perantara disini langsung mengambil kue telur gabus dari KWT Melati kemudian menjualnya kepada pedagang pengecer kemudian oleh pedagagang pengecer menjualnya kepada konsumen dengan berkeliling mencari konsumen satu persatu. Terdapat 2 (tiga) orang pedagang perantara yang bekerjasama dengan KWT Melati dan secara rutin membeli kue telur gabus dari KWT Melati dan terdapat 6 orang pedagang pengecer yang bekerjasama dengan pedagang perantara.

Adapun sistem pembayarannya adalah pedagang perantara mengambil dahulu kue telur gabus sejumlah yang diinginkan kemudian pada pekan berikutnya apabila kue telur gabus telah habis terjual baru pedagang perantara membayar nilai kue telur gabus yang dibelinya demikian juga dengan pedagang pengecer kepada pedagang perantara juga demikian.

Kue telur gabus yang disalurkan oleh KWT Melati kepada pedagang perantara terdiri dari tiga macam kemasan yaitu :

1). Kue telur gabus kemasan 10 gram dengan harga jual Rp 700/Bks yang kemudian dijual oleh pedagang perantara kepada pedagang pengecer rata-rata seharga Rp 850/Bks. Banyaknya kue telur gabus kemasan ini yang disalurkan KWT Melati kepada pedagang perantara dalam setiap kali proses produksi rata-rata adalah sebanyak 175 bungkus sehingga total nilai penjualan KWT Melati adalah sebesar Rp 122.500.

Oleh pedagang perantara kue telur gabus kemasan ini kemudian dijual kepada pedagang pengecer seharga Rp 850/Bks sehingga diperoleh nilai penjualan pedagang perantara sebesar Rp 148.750. Kemudian oleh pedagang pengecer kue telur gabus kemasan ini dijual kepada konsumen seharga Rp 1.000/Bks sehingga diperoleh nilai penjualan pedagang pengecer sebesar Rp 175.000.

2). Kemasan 100 gram dengan harga jual Rp 5.000/Bks yang kemudian dijual oleh pedagang perantara kepada pedagang pengecer seharga Rp 6.500/Bks. Banyaknya kue telur gabus kemasan ini yang disalurkan KWT Melati kepada pedagang perantara dalam setiap kali proses produksi rata-rata adalah sebanyak 36 bungkus sehingga total nilai penjualan KWT Melati adalah sebesar Rp 180.000.

Oleh pedagang perantara kue telur gabus kemasan ini kemudian dijual kepada pedagang pengecer seharga Rp 6.500/Bks sehingga diperoleh nilai penjualan pedagang perantara sebesar Rp 234.000. Kemudian oleh pedagang pengecer kue telur gabus kemasan ini dijual kepada konsumen seharga Rp 8.000/Bks sehingga diperoleh nilai penjualan pedagang pengecer sebesar Rp 288.000 .

3). Kemasan 200 gram dengan harga jual $\mathrm{Rp}$ 10.000/Bks yang kemudian dijual oleh pedagang perantara kepada pedagang pengecer seharga $\mathrm{Rp}$ 11.000/Bks. Banyaknya kue telur gabus kemasan ini yang disalurkan KWT Melati kepada pedagang perantara dalam setiap kali proses produksi rata-rata adalah sebanyak 4 bungkus sehingga total nilai penjualan KWT Melati adalah sebesar Rp 40.000.

Oleh pedagang perantara kue telur gabus kemasan ini kemudian dijual kepada pedagang pengecer seharga Rp $11.000 / \mathrm{Bks}$ sehingga diperoleh nilai penjualan 
pedagang perantara sebesar Rp 44.000. Kemudian oleh pedagang pengecer kue telur gabus kemasan ini dijual kepada konsumen rata-rata seharga Rp 15.000/Bks sehingga diperoleh nilai penjualan pedagang pengecer sebesar Rp 60.000.

Dalam saluran pemasaran ketiga ini, pedagang perantara mengeluarkan biaya pemasaran yaitu biaya transportasi dan biaya tenaga kerja karena barang dagangan diambil langsung oleh pedagang perantara di KWT Melati.

Tabel 8. Fungsi Tataniaga Setiap Lembaga Pemasaran pada Saluran III.

\begin{tabular}{clccc}
\hline No & Fungsi Tataniaga & Produsen & $\begin{array}{r}\text { Pedagang } \\
\text { Perantara }\end{array}$ & $\begin{array}{c}\text { Pedagang } \\
\text { Pengecer }\end{array}$ \\
\hline 1. & Fungsi & & & \\
& $\begin{array}{l}\text { Pertukaran } \\
\text { Penjualan }\end{array}$ & $\sqrt{ }$ & $\sqrt{ }$ & $\sqrt{ }$ \\
& $\begin{array}{l}\text { Pembelian } \\
\text { 2. }\end{array}$ Fungsi Fisik & - & $\sqrt{ }$ & $\sqrt{ }$ \\
& Pengangkutan & - & $\sqrt{ }$ & $\sqrt{ }$ \\
& Penyimpanan & - & $\sqrt{ }$ & $\sqrt{ }$ \\
3. & Pengemasan & $\sqrt{ }$ & - & - \\
& Fungsi Fasilitas & & & - \\
& Sortasi/Grading & $\sqrt{ }$ & - & - \\
& Penanggungan & $\sqrt{ }$ & - & - \\
& Resiko & $\sqrt{ }$ & - & \\
\hline
\end{tabular}

Sumber : Data Primer, 2020.

\section{Keuntungan, Margin Pemasaran dan Farmer's Share Kue Telur Gabus.}

\section{Keuntungan}

Biaya pemasaran adalah biaya-biaya yang dikeluarkan dalam proses perpindahan barang dari produsen ke konsumen akhir. Besar kecilnya biaya pemasaran untuk hasil produk kue telur gabus tergantung dari banyaknya kegiatan kelembagaan pemasaran dan jumlah fasilitas yang diperlukan dalam proses pemasaran tersebut. Biaya pemasaran mencakup sejumlah pengeluaran yang dilakukan untuk keperluan yang berhubungan dengan penjualan kue telur gabus. Lembaga pemasaran yang terlibat dalam proses pemasaran akan mengeluarkan biaya-biaya yang berbeda-beda, besarnya biaya pemasaran akan mempengaruhi harga produk yang dipasarkan serta keuntungan yang diperoleh.

Selain biaya, keuntungan merupakan hal yang menjadi pertimbangan dalam melakukan kegitan pemasaran. Menurut Soekartawi (2001), keuntungan pemasaran adalah selisih harga yang dibayarkan ke produsen dan harga harga yang diberikan ke konsumen. Biaya dan jarak yang mengantarkan produksi pertanian dari produsen ke konsumen menyebabkan terjadinya perbedaan besarnya keuntungan pemasaran.

Adapun rumus untuk mencari keuntungan pemasaran dan besarnya persentase keuntungan pemasaran maka digunakan rumus :

a. Keuntungan Pemasaran $=$ Total Penjualan - Biaya Pemasaran

b. Persentase Keuntungan $=$ (Keuntungan : Total Penjualan) $\times 100 \%$

Pada perhitungan tabel 8 menunjukkan bahwa nilai penjualan kue telur gabus KWT Melati langsung kepada konsumen pada saluran I adalah untuk telur gabus kemasan 10 gram adalah sebesar Rp 8.400, kemasan 100 gram adalah sebesar Rp 20.000 dan kemasan 200 gram adalah sebesar Rp 20.000 sehingga total nilai penjualan adalah sebesar Rp.48.400. KWT Melati tidak mengeluarkan biaya pemasaran karena konsumen langsung mendatangi sendiri tempat penjualan kue telur gabus sehingga KWT Melati tidak perlu mengeluarkan biaya tenaga kerja dan transportasi. Adapun besarnya keuntungan yang diperoleh KWT Melati adalah sebesar Rp 48.400 atau sebesar $100 \%$.

Tabel 9. Harga Beli, Harga Jual dan Keuntungan Masing - Masing Lembaga Pemasaran Kue Telur Gabus pada Saluran Pemasaran I, 2020.

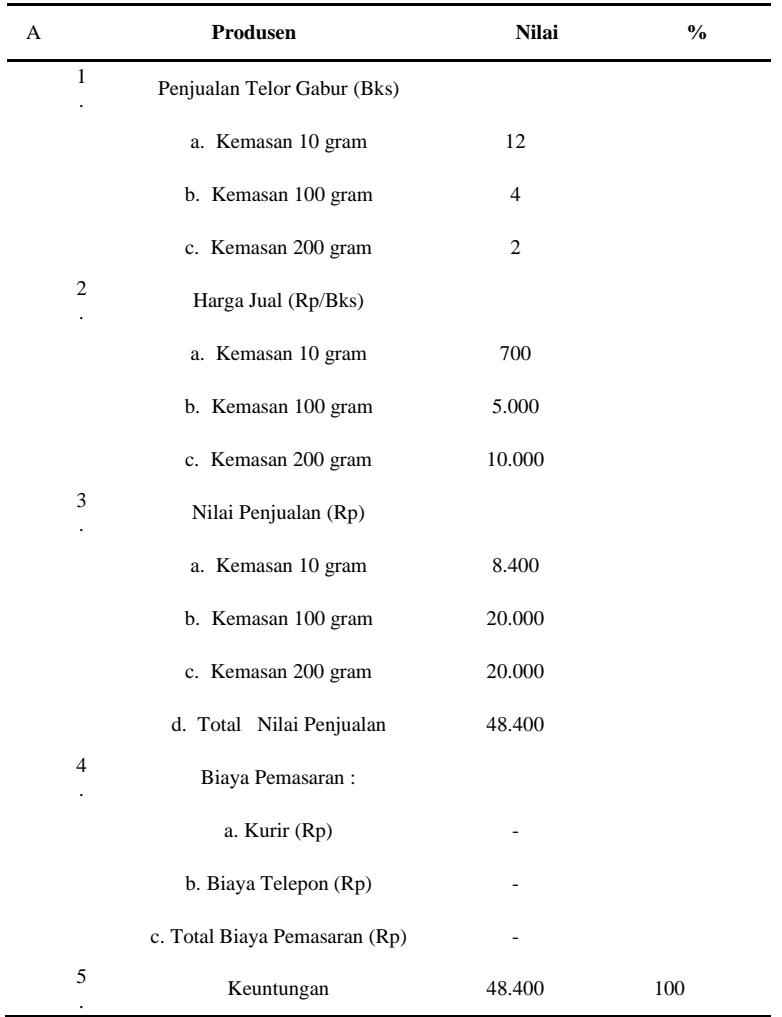

Sumber : Data Primer, 2020.

Tabel 9 menunjukkan bahwa nilai penjualan kue telur gabus KWT Melati kepada pedagang pengecer pada saluran II adalah untuk telur gabus kemasan 10 gram adalah sebesar Rp 91.000, kemasan 100 gram adalah sebesar Rp 145.000 dan kemasan 200 gram adalah sebesar Rp 110.000 sehingga total nilai penjualan adalah sebesar Rp 346.000. Pada saluran ini KWT Melati mengeluarkan biaya pemasaran yang digunakan untuk kurir untuk mengantarkan kue telur gabus tersebut kepada pedagang pengecer yaitu sebesar Rp 50.000 per proses produksi. Keuntungan pemasaran diperoleh dengan mengurangi nilai penjualan dengan biaya pemasaran sehingga diperoleh keuntungan sebesar Rp 296.000 atau sebesar 85,5\%.

Tabel 10. Harga Beli, Harga Jual dan Keuntungan Masing - Masing Lembaga Pemasaran Kue Telur Gabus pada Saluran Pemasaran II, 2020. 


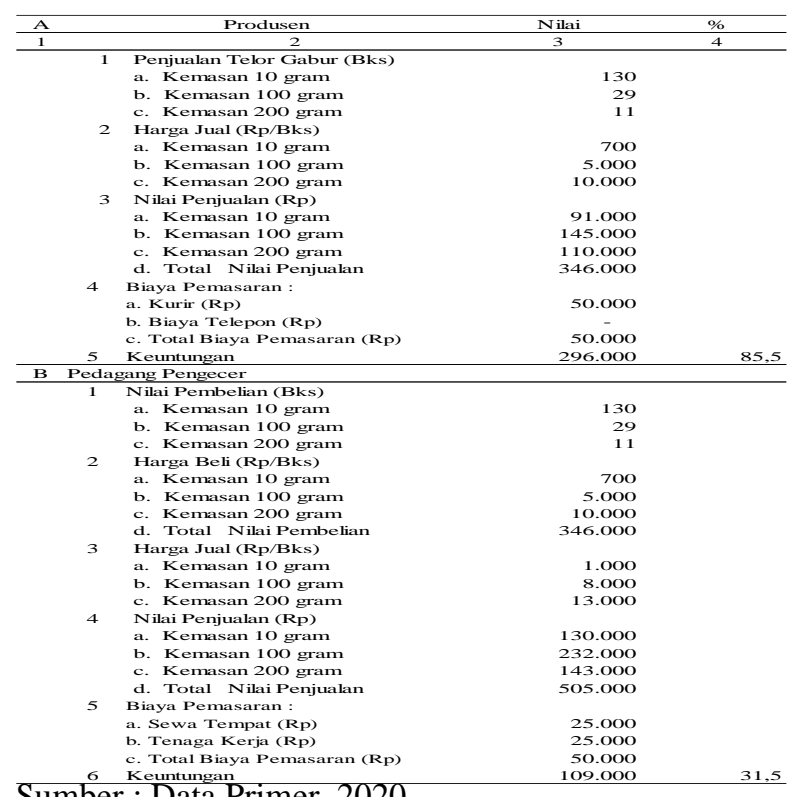

Sumber : Data Primer, 2020.

Penjualan kue telur gabus oleh pedagang pengecer kepada konsumen dilakukan di tempat pedagang perantara yaitu di kios atau warung dengan sistem pembayaran tunai. Kue telur gabus kemasan 10 gram dijual dengan harga rata-rata $\mathrm{Rp}$ 1.000/Bks, kemasan 100 gram dijual dengan harga Rp 8.000/Bks dan kemasan 200 gram dijual dengan harga Rp 13.000/Bks. Adapun nilai total penjualan kue telur gabus pedagang pengecer adalah sebesar Rp 505.000. Biaya pemasaran yang dikeluarkan pedagang pengecer digunakan untuk biaya tenaga kerja dan nilai sewa tempat adalah sebesar Rp 50.000 per proses produksi. Keuntungan pemasaran pedagang pengecer diperoleh dengan mengurangi nilai penjualan dengan nilai pembelian dan biaya pemasaran sehingga diperoleh keuntungan sebesar Rp 109.000 atau sebesar 31,5\%.

Tabel 10 menunjukkan bahwa nilai penjualan kue telur gabus KWT Melati kepada pedagang perantara pada saluran ketiga adalah untuk telur gabus kemasan 10 gram adalah sebesar Rp 122.500, kemasan 100 gram adalah rata-rata sebesar $\mathrm{Rp} 180.000$ dan kemasan 200 gram adalah sebesar Rp 40.000 sehingga total penjualan adalah sebesar Rp 342.500. KWT Melati tidak mengeluarkan biaya pemasaran karena pedagang perantara langsung mangambil sendiri kue telur gabus. Keuntungan diperoleh dengan mengurangi nilai penjualan dengan biaya pemasaran sehingga diperoleh keuntungan KWT Melati adalah sebesar Rp 342.500 atau sebesar $100 \%$.

Tabel 11. Harga Beli, Harga Jual dan Keuntungan Masing - Masing Lembaga Pemasaran Kue Telur Gabus pada Saluran Pemasaran III, 2020.

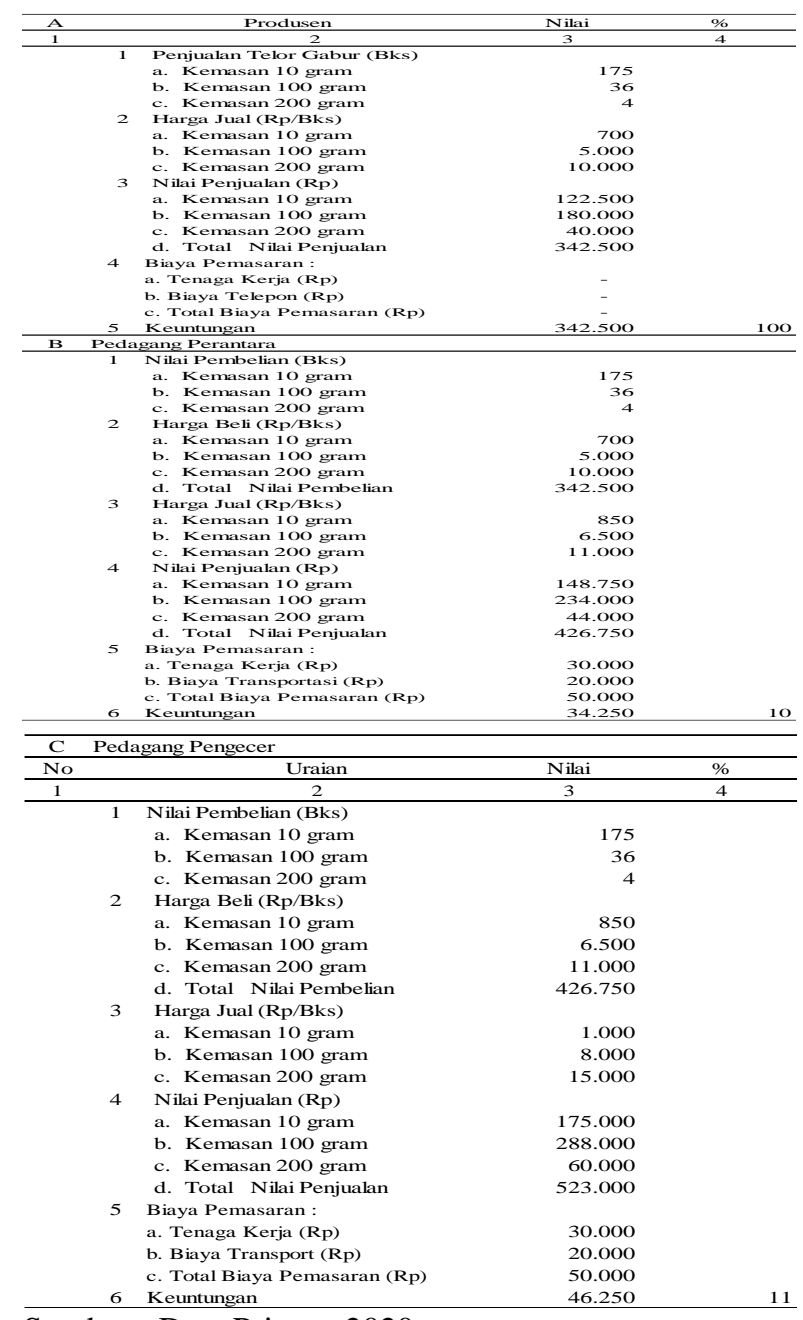

Sumber : Data Primer, 2020.

Penjualan kue telur gabus oleh pedagang perantara kepada pedagang pengecer dilakukan dengan cara pedagang pengecer mendatangi tempat pedagang perantara. Pedagang perantara menjaul kue telur gabus kemasan 10 gram dijual kepada pedagang pengecer dengan harga rata-rata $\mathrm{Rp}$ 850/Bks, kemasan 100 gram dijual dengan harga Rp 6.500/Bks dan kemasan 200 gram dijual dengan harga rata-rata $\mathrm{Rp} 11.000 / \mathrm{Bks}$. Adapun nilai total penjualan kue telur gabus pedagang perantara kepada pedagang pengecer rata-rata adalah sebesar Rp 426.7500. Biaya pemasaran yang dikeluarkan pedagang perantara digunakan untuk biaya tenaga kerja dan biaya transportasi saat membeli kue telur gabus dari KWT Melati yaitu sebesar Rp 50.000 per proses produksi. Keuntungan pemasaran pedagang perantara diperoleh dengan mengurangi nilai penjualan dengan nilai pembelian dan biaya pemasaran sehingga diperoleh keuntungan sebesar Rp 34.250 atau sebesar $10 \%$.

Penjualan kue telur gabus oleh pedagang pengecer kepada konsumen dilakukan dengan mendatangi konsumen satu persatu dari rumah ke rumah sistem pembayaran tunai. Oleh pedagang pengecer kue telur gabus kemasan 10 gram dijual kepada konsumen dengan harga rata-rata Rp 1.000/Bks, kemasan 100 gram dijual dengan harga Rp 8.000/Bks 
dan kemasan 200 gram dijual dengan harga rata-rata Rp 15.000/Bks. Adapun nilai total penjualan kue telur gabus pedagang pengecer adalah sebesar Rp 523.000. Biaya pemasaran yang dikeluarkan pedagang pengecer digunakan untuk biaya tenaga kerja dan transportasi adalah sebesar Rp 50.000 per proses produksi. Pedagang pengecer mengeluarkan biaya pemasaran yang digunakan untuk biaya tenaga kerja dan biaya transportasi saat menjual kue telur gabus kepada konsumen yaitu sebesar Rp 50.000 per proses produksi. Adapun keuntungan pemasaran diperoleh dengan mengurangi nilai penjualan dengan nilai pembelian dan biaya pemasaran sehingga diperoleh keuntungan pedagang pengecer adalah sebesar Rp 46.250 atau sebesar $11 \%$.

\section{Margin Pemasaran}

Margin pemasaran adalah perbedaan harga atau selisih harga yang dibayar konsumen dengan harga yang diterima produsen, atau dapat juga dinyatakan sebagai nilai dari jasa-jasa pelaksanaan kegiatan tataniaga sejak dari tingkat produsen sampai ke titik konsumen akhir. Tinggi rendahnya margin tataniaga sering digunakan sebagai kriteria untuk penilaian apakah pasar tersebut sudah efisien atau belum, tetapi margin tataniaga tidak selamanya dapat digunakan sebagai ukuran efisiensi kegiatan tataniaga. Menghitung besarnya margin pemasaran yang diterima pada setiap masing- masing saluran pemasaran, digunakan rumus yaitu :

$\mathrm{Mpi}=\mathrm{Hj}-\mathrm{Hb}$

$\mathrm{Mp}=$ Margin pemasaran ke-i $(\mathrm{Rp} / \mathrm{Kg})$

$\mathrm{Hj}=$ Harga jual ke-i $(\mathrm{Rp} / \mathrm{Kg})$

$\mathrm{Hb}=$ Harga beli ke-i $(\mathrm{Rp} / \mathrm{Kg})$

a.Margin Pemasaran Saluran I (Produsen ke Konsumen).

1. Kemasan 10 gram $\quad=$ Harga Jual - Harga Beli $=700-700$

$$
=0
$$

2. Kemasan 100 gram $=$ Harga Jual - Harga Beli $=5.000-5.000$

$=0$

3. Kemasan 200 gram $=$ Harga Jual - Harga Beli $=10.000-10.000$ $=0$

b.Margin Pemasaran Saluran II (Produsen ke Pedagang Pengecer ke Konsumen).

$\begin{aligned} \text { 1. Kemasan 10 gram } & =\text { Harga Jual ke Konsumen - Harga Beli } \\ & =1.000-700 \\ & = \\ \text { 2. Kemasan } 100 \text { gram } & \\ & =8.000-5.000 \\ & =3.000 \\ & \\ \text { 3. Kemasan 200 gram } & \text { Harga Jual ke Konsumen - Harga Beli } \\ = & 13.000-10.000 \\ = & 3.000\end{aligned}$

c.Margin Pemasaran Saluran III (Pedagang Perantara ke Pedagang Pengecer).

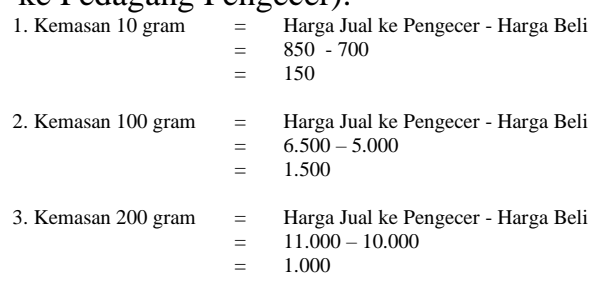

d.Margin Pemasaran Saluran III (Pedagang Pengecer ke Konsumen).

$\begin{aligned} \text { 1. Kemasan 10 gram } & =\text { Harga Jual ke Konsumen - Harga Beli } \\ & =1.000-850 \\ & =150 \\ \text { 2. Kemasan 100 gram } & =\text { Harga Jual ke Konsumen - Harga Beli } \\ & =8.000-6.500 \\ & =1.500 \\ \text { 3. Kemasan 200 gram } & =\text { Harga Jual ke Konsumen - Harga Beli } \\ & =15.000-11.000 \\ & =4.000\end{aligned}$

Tabel 12. Margin Pemasaran dan Farmer's Share Pemasaran Kue Telur Gabus KWT Melati, 2020.

\begin{tabular}{|c|c|c|c|c|c|c|c|c|}
\hline & & Produsen & \multirow[t]{2}{*}{ P. Perantara } & \multirow[t]{2}{*}{ P. Pengecer } & \multirow[t]{2}{*}{ Konsumen } & \multirow{2}{*}{\multicolumn{2}{|c|}{ Margin }} & \multirow{2}{*}{$\begin{array}{l}\text { Farmer } \\
\text { Share }(\%)\end{array}$} \\
\hline A. & Saluran I & & & & & & & \\
\hline 1 & 2 & 3 & 4 & 5 & 6 & 7 & & 8 \\
\hline 1. & Harga Beli & & & & & & & \\
\hline & 10 gram & - & - & - & 700 & 0 & & \\
\hline & 100 gram & - & - & - & 5.000 & 0 & & \\
\hline & 200 gram & - & - & - & 10.000 & 0 & & \\
\hline 2. & Harga Jual & & & & & & & \\
\hline & 10 gram & 700 & - & - & - & & & 100 \\
\hline & 100 gram & 5.000 & - & - & - & & & 100 \\
\hline & 200 gram & 7.000 & - & - & - & & & 100 \\
\hline B. & Saluran II & & & & & & & \\
\hline 1. & Harga Beli & & & & & & & \\
\hline & 10 gram & - & - & 700 & 1.000 & 300 & & \\
\hline & 100 gram & - & - & 5.000 & 8.000 & 3.000 & & \\
\hline & 200 gram & - & - & 10.000 & 13.000 & 3.000 & & \\
\hline 2. & Harga Jual & & & & & & & \\
\hline & 10 gram & 700 & - & - & - & & & 70 \\
\hline & 100 gram & 5.000 & - & - & - & & & 63 \\
\hline & 200 gram & 7.000 & - & - & - & & & 54 \\
\hline C. & Saluran III & & & & & & & \\
\hline 1. & Harga Beli & & & & & & & \\
\hline & 10 gram & & 700 & 850 & 1.000 & 150 & 150 & \\
\hline & 100 gram & & 5.000 & 6.500 & 8.000 & 1.500 & 1.500 & \\
\hline & 200 gram & & 10.000 & 11.000 & 15.000 & 1.000 & 4.000 & \\
\hline 2. & Harga Jual & & & & & & & \\
\hline & 10 gram & 700 & 850 & 1.000 & - & & & 70 \\
\hline & 100 gram & 5.000 & 6.500 & 8.000 & - & & & 63 \\
\hline & 200 gram & 10.000 & 11.000 & 15.000 & - & & & 67 \\
\hline
\end{tabular}

Sumber : Data Primer, 2020.

Berdasarkan perhitungan pada tabel 12 menunjukkan bahwa harga jual kue telur gabus KWT Melati kepada konsumen pada saluran I masing masing untuk kemasan 10 gram adalah sebesar Rp 700/Bks, kemasan 100 gram sebesar Rp 5.000/Bks dan kemasan 200 gram sebesar Rp 10.000/Bks. Nilai margin pemasaran KWT Melati sebagai produsen ke konsumen adalah untuk kemasan 10 gram, kemasan 100 gram maupun kemasan 200 gram nilai marginnya adalah sebesar Rp 0/Bks, diperoleh besarnya nilai margin sebesar Rp 0/Bks

Pada perhitungan tabel 12 dapat diketahui bahwa harga jual kue telur gabus KWT Melati kepada pedagang pengecer pada saluran II untuk kemasan 10 gram adalah sebesar Rp 700/Bks, kemasan 100 gram Rp 5.000/Bks dan kemasan 200 gram Rp 10.000/Bks. Kemudian pedagang pengecer melakukan penjualan ke konsumen dengan harga untuk kemasan 10 gram adalah sebesar Rp 1.000/Bks, kemasan 100 gram Rp 8.000/Bks dan kemasan 200 gram Rp 13.000/Bks sehingga memperoleh keuntungan untuk kemasan 10 gram sebesar Rp 300/Bks, untuk kemasan 100 gram sebesar Rp 3.000/Bks dan untuk kemasan 200 gram sebesar Rp 3.000/Bks. 
Nilai margin pemasaran KWT Melati sebagai produsen ke konsumen adalah untuk kemasan 10 gram adalah sebesar Rp 300/Bks, kemasan 100 gram nilai margin sebesar Rp 3.000/Bks dan kemasan 200 gram nilai margin adalah sebesar Rp 3.000/Bks. Nilai margin harga terbesar diperoleh dari penjualan telur gabus kemasan 100 gram dan 200 gram dengan nilai margin pemasaran sebesar Rp 3.000/Bks.

Pada perhitungan tabel 12 juga dapat diketahui bahwa harga jual kue telur gabus KWT Melati kepada pedagang perantara pada saluran III untuk kemasan 10 gram adalah sebesar Rp 700/Bks, kemasan 100 gram adaah sebesar Rp 5.000/Bks dan untuk kemasan 200 gram adalah sebesar Rp 10.000/Bks. Kemudian pedagang perantara melakukan penjualan kepada pedagang pengecer dengan harga untuk kemasan 10 gram adalah sebesar Rp 850/Bks, kemasan 100 gram sebesar Rp 6.500/Bks dan kemasan 200 gram sebesar Rp 11.000/Bks sehingga memperoleh keuntungan untuk kemasan 10 gram sebesar Rp 150/Bks, kemasan 100 gram sebesar Rp 1.500/Bks dan kemasan 200 gram sebesar Rp 1.000/Bks.

Nilai margin yang diperoleh pedagang perantara adalah untuk kemasan 10 gram sebesar Rp 150/Bks, kemasan 100 gram nilai margin sebesar Rp 1.500/Bks dan kemasan 200 gram nilai margin adalah sebesar Rp 1.000/Bks, sehingga diperoleh total margin pemasaran pedagang perantara pada saluran pemasaran III adalah sebesar Rp 2.650. Nilai margin harga terbesar diperoleh dari penjualan kue telur gabus kemasan 100 gram dengan nilai margin sebesar Rp 1.500/Bks.

Berdasarkan hasil analisis pada tabel 12 juga diketahui bahwa harga jual kue telur gabus pedagang pengecer kepada konsumen pada saluran pemasaran III masing masing untuk kemasan 10 gram adalah sebesar Rp 1.000/Bks, kemasan 100 gram Rp 8.000/Bks dan kemasan 200 gram Rp 15.000/Bks sehingga memperoleh keuntungan untuk kemasan 10 gram sebesar Rp 150/Bks, kemasan 100 gram sebesar Rp 1.500/Bks dan kemasan 200 gram sebesar Rp 4.000/Bks.

Nilai margin yang diperoleh pedagang pengecer adalah untuk kemasan 10 gram sebesar Rp 150/Bks, kemasan 100 gram nilai margin sebesar Rp 1.500/Bks dan kemasan 200 gram nilai margin adalah sebesar Rp 4.000/Bks, sehingga diperoleh total margin pemasaran pedagang pengecer pada saluran pemasaran III adalah sebesar Rp 5.650. Nilai margin harga terbesar diperoleh dari penjualan kue telur gabus kemasan 200 gram dengan nilai margin sebesar Rp 4.000/Bks.

Berdasarkan analisis yang telah dilakukan maka diketahui bahwa nilai margin pemasaran kue telur gabus KWT Melati pada saluran II lebih besar dibandingkan nilai margin pemasaran pada saluran pemasaran I dan III.

\section{Farmer's Share}

Untuk mengetahui besarnya bagian yang diterima KWT Melati digunakan konsep Farmer's share. Farmer's share adalah persentasi bagian harga yang diterima oleh produsen dalam suatu sistem pemasaran produk usaha pembuatan telur gabus agar dapat sampai konsumen akhir. Farmer's share dapat dijadikan dasar atau tolok ukur efisiensi pemasaran. Semakin tinggi persentase farmer's share, maka semakin efisien kegiatan pemasaran yang dilakukan. Sebaliknya, semakin rendah persentase farmer's share, maka semakin rendah pula tingkat efisiensi dari suatu pemasaran. Untuk menghitung besarnya farmer's share produsen kue telur gabus maka dihitung dengan menggunakan rumus :

$$
\text { If }=\frac{P f}{P r} x 100 \%
$$

Dimana :

If = Farmer's share $(\%)$

$\mathrm{P} f=$ Harga ditingkat produsen $(\mathrm{Rp} / \mathrm{Bks})$

$\operatorname{Pr}=$ Harga ditingkat konsumen $(\mathrm{Rp} / \mathrm{Bks})$

a.Farmer's Share Saluran I

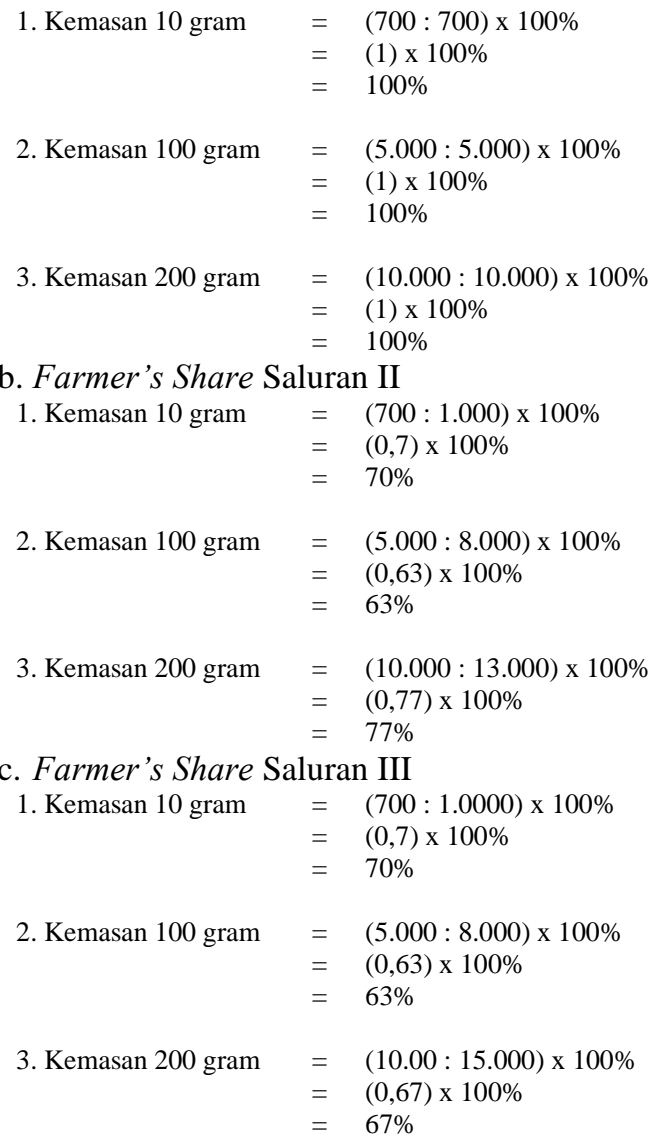

Berdasarkan data pada tabel 12 di atas dapat diketahui bahwa persentase bagian harga yang diterima oleh KWT Melati pada saluran pemasaran I untuk kue telur gabus kemasan 10 gram, kemasan 100 gram dan kemasan 200 gram adalah sama yaitu sebesar 100\% Nilai farmer's share KWT Melati pada saluran pemasaran I untuk semua kemasan diperoleh nilai yang sama karena KWT langsung menjual kue telur gabus kepada kosumen sehingga diperoleh harga jual produsen dan harga beli konsumen sama nilainya.

Berdasarkan data pada tabel 12 diatas juga dapat diketahui bahwa nilai farmer's share KWT Melati pada saluran pemasaran II untuk penjualan kue telur gabus kemasan 10 gram adalah sebesar $70 \%$, 
kemasan 100 gram sebesar 63\% dan untuk kemasan 200 gram sebesar 77\%. Nilai farmer's share terbesar diperoleh dari penjualan kue telur gabus kemasan 200 gram yaitu sebesar $77 \%$.

Berdasarkan data pada tabel 12 juga dapat diketahui bahwa nilai farmer's share KWT Melati pada saluran pemasaran III untuk kue telur gabus kemasan 10 gram adalah sebesar $70 \%$, kemasan 100 gram sebesar $63 \%$ dan kemasan 200 gram sebesar $67 \%$. Farmer Share terbesar diperoleh dari penjualan kue telur gabus kemasan 10 gram yaitu sebesar $70 \%$. Berdasarkan pengolahan data di atas dapat diketahui bahwa nillai farmer's share saluran pemasaran I lebih besar daripada nilai farmer's share saluran pemasaran II dan III, sehingga saluran pemasaran I lebih efisien dan menguntungkan daripada saluran pemasaran II dan III. Hal ini sesuai dengan pendapat Nasrudin (2006), yang mengatakan bahwa tataniaga dapat dikatakan semakin efisien jika semakin tinggi bagian harga (farmer's share) yang diterima petani.

\section{V.KESIMPULAN DAN SARAN}

\section{A. Kesimpulan}

Berdasarkan hasil penelitian ini, maka kesimpulan yang dapat dimbil adalah sebagai berikut :

1. Total biaya produksi usaha pengolahan kue telur gabus KWT Melati dalam satu kali proses adalah sebesar Rp 625.144, penerimaan sebesar Rp 736.900, pendapatan sebesar Rp 111.756. Nilai $\mathrm{R} / \mathrm{C}$ rasio sebesar 1,18 menunjukan bahwa usaha pengolahan kue telur gabus menguntungkan.

2. Terdapat tiga pola rantai pemasaran kue telur gabus yang melibatkan pedagang perantara dan pedagang pengecer .

3. Keuntungan pemasaran pada saluran I adalah $100 \%$ dengan margin pemasaran sebesar Rp 0/Bks, keuntungan pemasaran saluran II sebesar $85,5 \%$ dan $31,5 \%$ dengan margin pemasaran sebesar Rp 300/Bks, Rp 3.000/Bks dan Rp 3.000/Bks dan keuntungn pemasaran saluran III masing-masing $100 \%, 10 \%$ dan $11 \%$ dengan margin pemasaran masing-masing sebesar Rp 150/Bks, Rp 1.500/Bks dan Rp 1.000/Bks serta Rp 150/Bks, Rp 1.500/Bks dan Rp 4.000/Bks.

4. Nilai farmer's share saluran pemasaran I adalah sebesar $100 \%$, saluran pemasaran II rata-rata adalah sebesar $74 \%$, dan saluran pemasaran III rata-rata adalah sebesar $65 \%$. Saluran pemasaran I lebih efisien daripada saluran pemasaran II dan III.

\section{B. Saran}

Adapun saran yang dapat direkomendasikan berdasarkan hasil penelitian ini adalah sebagai berikut :

1. Hendaknya KWT Melati dalam pengolahan kue telur gabus agar tetap memperhatikan dan menjaga kualitas produksi yang dihasilkan.

2. Hendaknya KWT Melati agar lebih berinovasi lagi dalam menghasilkan kue telur gabus yaitu dengan mengembangkan berbagai varian rasa kue telur gabus yang dihasilkan sehingga akan lebih menarik lagi.

3. Pemerintah melalui institusi atau dinas-dinas terkait agar melakukan pembinaan dan memberikan bantuan modal usaha kepada industri mikro sehingga dapat lebih berkembang lagi.

\section{DAFTAR PUSTAKA}

Soekartawi, 2002. Analisis Usahatani Universitas Indonesi. Jakarta.

Sjarkowi, F. dan Marwan, S. 2004. Manajemen Agribisnis, Palembang. 2006. Analisis usaha Tani. Universitas Indonesia. Jakarta.

Sjarkowi, F. 2010. Memejemen Pembangunan Agribisnis. Palembang. CV Baldad Grafiti Press. Palembang.

Ilahude, Mega Artha. 2013. Analisis Sistem Pemasaran Kopra di Kabupaten Gorontalo (Suatu Studi di Kecamatan Limboto). Skripsi. Jurusan Agribisnis Fakultas Pertanian Universitas Negeri Gorontalo.

Nadhwatunnaja, Nusrat. 2008. Analisis Pendapatan Usahatani dan Faktor- Faktor yang Mempengaruhi Produksi Paprika Hidroponik di Desa Pasir Langu, Kecamatan Cisarua, Kabupaten Bandung. Skripsi. Program Sarjana Ekstensi Manajemen Agribisnis Fakultas Pertanian Institut Pertanian Bogor.

Sa'id, Gumbria, dkk. 2001. Manajemen Teknologi Agribisnis (Kunci Menuju Daya Saing Global Produk Agribisnis. Ghalia Indonesia; Jakarta.

Suratiyah, Ken. 2015. Ilmu Usahatani. Penebar Swadaya : Jakarta. 